\section{index to adverlisers}

c 3 Alden

153 Belfort Instrument Co.

c 4 The Bendix Corporation

c 2 EG\&G, Inc.

174 Environmental Instruments, Inc

173 McGraw-Hill Book Co.

151 Olin Corporation

132 Science Associates

147 Texas Electronics, Inc.

AMS Notices (Publications, Preprints, etc.)

159 Macelwane-Orville-Hanks Scholarship Awards

163 Preprint Volume, Conference on Urban Environment and Second Conference on Biometeorology

167 Monthly Weather Review

181 Workshop on Micrometeorology

182 Conference on Cloud Physics

191 Meteorology of the Southern Hemisphere

192 AMS Employment Announcements

192 Conference on Air Pollution Meteorology

The deadline for advertising insertion orders is the 15th, two months prior to date of issue. Orders received after deadline are subject to space availability. Deadline for copy and/or plate is the lst day of month, one month prior to date of issue. For advertisting information contact: Evelyn Mazur, American Meteorological Society, 45 Beacon Street, Boston, Mass. 02108. Tel. 617-227-2425.

\section{employment announeements}

The American Meteorological Society issues employment announcements monthly, setting forth opportunities for positions in the atmospheric and oceanographic fields. The employers describe the prerequisites and requirements for the openings.

Members and nonmembers of the AMS may subscribe to the announcements. The subscription price for twelve monthly issues is $\$ 3$ per annum for AMS members and $\$ 12$ per annum for non-members (AMS student members free).

The purpose of the Employment Bulletin is to provide a means by which those seeking positions in the atmospheric and related fields and those requiring personnel to fill such openings may have a convenient means of communication. Organizations that wish to avail themselves of this service should contact the American Meteorological Society for details and charges.

\section{CONFERENCE ON AIR POLLUTION
METEOROLOGY}

\author{
April 5-9, 1971 \\ Raleigh, N.C.
}

A Conference on Air Pollution Meteorology, sponsored by the American Meteorological Society in cooperation with the Air Pollution Control Association was held on April 5-9, 1971 in Raleigh, N.C.

The conference provided a forum for the expression of views by both control officials and meteorologists on the role our science and technology serves toward the abatement of air pollution. It also presented an across-theboard accounting of the present state of knowledge, capabilities, and future needs to the extent that present perspective permits. The wide scope of the problems on air pollution meteorology, ranging from micro to global scales, and their basically interdisciplinary nature were emphasized. Extended abstracts of the papers presented at the conference are contained in a Preprint Volume under the following topics:

METEOROLOGY IN AIR RESOURCES MANAGEMENT AIR TRANSPORT AND DIFFUSION IN URBAN AREAS

ATMOSPHERIC TURBULENCE AND DIFFUSION PLUME DISPERSION

TRANSFORMATION AND REMOVAL PROCESSES IN THE ATMOSPHERE

AIR POLLUTION CLIMATOLOGY AND FORECASTS

WEATHER AND CLIMATE MODIFICATION BY AIR POLLUTANTS GENERAL SESSION I GENERAL SESSION II

\$15 AMS Members 160 pages $\$ 20$ Nonmembers

Send orders and remittance to:

\section{AMERICAN METEOROLOGICAL SOCIETY 45 BEACON STREET BOSTON, MASS. 02108}

